\title{
GEJALA FUNDAMENTALISME AGAMA DI INDONESIA: MEMBACA HIZBUT TAHRIR INDONESIA SEBAGAI GERAKAN SOSIAL
}

\author{
Muhammad Sabri \\ Universitas Islam Negeri (UIN) Alauddin Makassar, Indonesia \\ Email: mohdsabriar@yahoo.co.id \\ Muh. Ikhsan \\ Institut Agama Islam Negeri (IAIN) Kendari, Indonesia \\ Email: ichank_ar@yahoo.co.id \\ Ismail Suardi Wekke \\ Sekolah Tinggi Agama Islam Negeri (STAIN) Sorong, Indonesia \\ Email: iswekke@gmail.com \\ Presented in \\ International Conference on Ethics in Governance (ICONEG) 2016 \\ Makassar, December 19-20, 2016
}

\begin{abstract}
ABSTRAK
Gejala fundamentalisme Islam - termasuk Hizbut Tahrir Indonesia, selanjutnya disebut HTIpada umumnya berasal dari negara-negara Timur Tengah yang diadaptasi mahasiswa Indonesia yang menempuh studi di sana. Di Indonesia, HTI mulai muncul dan dikenalkan oleh AlBaghdadi dan Musthofa sejak tahun 1982. Tulisan ini menganalisis HTI sebagai gerakan sosial (social movement) yang dapat dikenali melalui tiga kategori: pertama, HTI adalah gerakan spesifik, yang terobsesi untuk menerapkan hukum Islam secara menyeluruh melalui negara khilafah. Kedua, HTI merupakan gerakan radikal yang bermaksud menerapkan sistem Islam dalam setiap sendi kehidupan. Ketiga, HTI merupakan gerakan yang berusaha mengembalikan tatanan Islam sebagai pusat peradaban dunia. Meski demikian, dalam meraih cita-citanya itu, HTI tidak menggunakan pendekatan kekerasan.
\end{abstract}

Katakunci: Fundamentalisme Islam, Hizbut Tahrir Indonesia, Gerakan Sosial

\section{A. Pendahuluan}

Akumulasi yang terus bertambah perihal kisah perlawanan politik dan gerakan-gerakan penentangan terhadap rezim kekuasaan yang dianggap otoriter dan represif di seantero jagat. Para ahli ilmu sosial umumnya menempatkan fenomena Revolusi Perancis pada abad ke-18 sebagai akar tunjang dari munculnya gerakan sosial di dunia. Peristiwa-peristiwa sosial serupa berlangsung melintasi abad ke-19 dan abad ke-20 bahkan hingga milinium ke-3 kini. Termasuk dalam soal pemisahan agama dan Negara (Wekke, 2016).

Para ahli umumnya sepakat bahwa dalam beberapa dekade terakhir, variasi, frekuensi dan intensi gerakan dan perlawanan politik semakin bertambah dan kompleks. Ini antara lain tampak dari munculnya gerakan hak-hak sipil di Amerika Serikat, gerakan-gerakan perdamaian, lingkungan, dan feminis, serta perlawanan terhadap otoritarianisme baik di Eropa maupun di 
negara-negara berkembang telah membawa massa ke jalan-jalan untuk menuntut perubahan. Hal yang sama dilakukan oleh kaum ekstrimisme religius Islam dan Yahudi di negara-negara Timur Tengah, militanisme Hindu di India, fundamentalisme Kristen di Amerika Serikat, serta nasionalisme etnis di Balkan dan bekas Uni Sovyet. Gerakan- gerakan itu acap kali sukses, tetapi jika pun mereka gagal, aksi-aksi mereka telah memengaruhi perubahan-perubahan politik, kultural, dan bahkan internasional.

Gerakan dan perlawanan politik serupa itu juga terus bermunculan di Indonesia. Dari jejak historis kita memiliki khasanah dokumentasi tentang pemberontakan petani pada masa kolonial, gerakan nasionalisme pada awal abad ke-20, gerakan demokratisasi, gerakan feminisme dan gerakan lingkungan pada masa Orde Baru hingga kini, serta gerakan "anti-globalisasi" sejak akhir tahun 1990-an hingga kini. Kesemua itu telah menimbulkan banyak perubahan berarti di negeri nusantara ini.

Dalam upaya memahami dan menjelaskan fenomena tersebut, para ahli ilmu sosial telah mengembangkan khasanah pengetahuan dan wacana yang sangat kaya dan terus berkembang hingga kini. Pada dataran teoretis, hal ini telah melahirkan berbagai teori tentang gerakan sosial. Beberapa diantaranya adalah teori tindakan kolektif (collective action/behavior), teori nilai tambah (value added) J. Smelser, teori mobilisasi sumberdaya (resource mobilization), teori proses politik (political process), dan teori gerakan sosial baru (new social movement). Artikel ini utamanya merujuk kepada teori proses politik yang dikembangkan Sydney Tarrow (1998) dan Doug McAdam (2004), serta teori gerakan sosial baru (GSB) yang telah diadopsi secara luas dalam kajian-kajian tentang gerakan sosial di dunia.

Senapas dengan detak perkembangan teori gerakan sosial yang kian jamak, tidak ada definisi tunggal mengenai konsep gerakan sosial sebagai suatu gejala sosial. Giddens (1993: 642) misalnya, mendefinisikan gerakan sosial sebagai upaya kolektif untuk mengejar suatu kepentingan bersama, atau mencapai tujuan bersama melalui tindakan kolektif (collective action) di luar lingkup lembaga-lembaga yang mapan. Definisi senada dirumuskan teoretisi terkemuka Sydney Tarrow (1998:4) gerakan sosial adalah tantangan-tantangan kolektif yang didasarkan pada tujuan-tujuan bersama dan solidaritas sosial, dalam interaksi yang berkelanjutan dengan para elite penentang dan pemegang wewenang. Dari dua definisi ini mengandaikan gerakan sosial sebagai tindakan kolektif yang bersifat menentang untuk merengkuh tujuan kolektif pula.

Ini merupakan definisi yang luas, karena gerakan sosial memiliki paras yang jamak.. Gerakan sosial bisa dalam bentuk kelompok kecil dan terbatas, hingga ribuan bahkan jutaan orang. Gerakan sosial bisa pula beroperasi dalam tataran legalitas-formal suatu masyarakat namun bisa juga bergerak secara ilegal atau sebagai kelompok "bawah tanah" (underground groups).

Tarrow (1998) menempatkan gerakan sosial di dalam kategori yang lebih umum sebagai politik perlawanan (contentius politics). Politik perlawanan bisa mencakup gerakan sosial, siklus penentangan (cycles of contention) dan revolusi. Politik perlawanan terjadi ketika rakyat biasa dan para warga yang lebih berpengaruh, menggalang kekuatan bersama untuk melawan para elite pemegang otoritas, dan pihak-pihak lawan lainnya. Perlawanan seperti ini biasanya muncul ketika kesempatan dan hambatan politik tengah berubah dan menciptakan dorongan bagi aktoraktor sosial yang kurang memiliki sumberdaya pada dirinya sendiri. Ketika perlawanan didukung oleh jaringan sosial yang kuat dan digerakkan oleh resonansi kultural dan simbol-simbol aksi, maka politik perlawanan mengarah ke interaksi yang berkelanjutan dengan pihak-pihak lawan, dan hasilnya adalah gerakan sosial. 
Menurut Tarrow, tindakan yang mendasari politik perlawanan adalah aksi kolektif yang melawan (contentius collective action). Tindakan kolektif bisa mengambil banyak bentuk: singkat atau berkelanjutan, terlembagakan atau cepat bubar, membosankan atau dramatis. Kebanyakan tindakan kolektif berlangsung dalam institusi ketika orang-orang yang tergabung di dalamnya bertindak untuk mencapai tujuan bersama. Aksi kolektif memiliki nuansa penentangan ketika aksi itu diakukan oleh orang-orang yang kurang memiliki akses ke institusi-institusi untuk mengajukan klaim baru atau klaim yang tidak dapat diterima oleh pemegang otoritas atau pihakpihak yang ditentang lainnya. Aksi kolektif yang melawan merupakan basis dari gerakan sosial, karena aksi itu seringkali merupakan satu-satunya sumberdaya yang dimiliki oleh orang-orang awam dalam menentang pihak-pihak lain yang lebih kuat, seperti negara

Meski demikian tidak dengan sendirinya berarti setiap bentuk perlawanan politik yang bertebaran di berbagai belahan dunia bisa disebut sebagai gerakan sosial. Bagi Tarrow (1998: 47), konsep gerakan sosial harus memiliki empat properti dasar. Pertama, tantangan kolektif (collective challenge). Gerakan sosial selalu ditandai oleh tantangan-tantangan untuk melawan melalui aksi langsung yang mengganggu para elite dan pemegang otoritas. Kedua, tujuan bersama (common purpose). Ketiga, Solidaritas dan identitas kolektif. Sesuatu yang menggerakan secara bersama-sama (common denominator) biasanya bersumber dari nasionalisme, etnisitas, atau keyakinan agama. Keempat, Memelihara politik perlawanan. Karena itu, memelihara aksi kolektif dalam interaksi dengan pihak lawan yang kuat menandai titik pergeseran di mana suatu penentangan (contention) berubah menjadi suatu gerakan sosial. Di titik ini, artikel ini mencoba mengkaji lebih jauh corak gerakan sosial Hizbut Tahrir Indonesia (HTI).

\section{B. Metode}

Artikel ini berbasis library research, maka sumber datanya diperoleh dari bahan-bahan pustaka terutama karya-karya yang menyangkut gerakan sosial HTI. Penelitian ini bersifat deskriptif analisis-kritis dengan pendekatan sosio-historis (Bambang Suggono, 2001:4) dan menggunakan analisis kualitatif. Metode deskriptif digunakan untuk memaparkan gambaran obyektif untuk kemudian diolah, diinterpretasikan dan dievaluasi. Sementara itu metode analisiskritis dimaksudkan memberi penasifan dan analisis secara kritis gagasan maupun rangkain aksi terkait gerakan sosial HTI.

Data-data dan dokumen yang diperoleh dikelompokkan menjadi data primer, yaitu tulisan-tulisan yang berhubungan dengan HTI meliputi gagasan, aksi dan tokohnya. Sementara data sekunder berupa tulisan atau sumber lainnya yang relevan dengan artikel ini.

\section{Pembahasan}

William Montgomery Watt—seperti dikutip Bahtiar Effendy (1996:95)—mengandaikan, hampir setiap Muslim meyakini akan pentingnya prinsip-prinsip Islam dalam kehidupan politik. Akan tetapi bagaimana pendapat ini dituangkan dalam bentuk kehidupan politik yang lebih riil masih terdapat perbedaan. Sejauh yang dapat ditangkap dari perjalanan diskursus pemikiran dan aktivisme politik Islam tidak ada kata sepakat khususnya menyangkut bentuk dan isi hubungan antara Islam dan sistem politik modern (demokrasi). 
Tema pemikiran Islam sebagai ideologi politik — dalam konteks wilayah dan kurun waktu yang tak terbatas - merupakan bagian dari pergulatan wacana gerakan sosial kebangkitan Islam. Ketika gerakan Islam telah mewujud ke dalam sebuah kekuatan praksis politik, maka nilai-nilai politis dalam dimensi keagamaan dengan sendirinya menjadi bagian yang tak terpisahkan. Di titik ini, ketegangan antara "wacana hegemonik" dan "nilai-nilai fundamentalisme Islam" terus berseteru dalam dua ranah praksis gerakan Islam: agama dan negara. Sejauh yang dapat ditangkap dari perjalanan diskursus intelektual dan historis, sedikitnya ada tiga spektrum pemikiran perihal relasi agama dan negara.

Pertama, pandangan yang meletakkan Islam bukan semata-mata menata relasi manusia dengan Tuhan, tetapi suatu sistem ajaran lengkap yang mengatur segenap napas kehidupan manusia, termasuk kehidupan bernegara (Ainur Rofiq al-Amin, 2012: 17). Kedua, perspektif yang mengandaikan Islam sama sekali tidak memiliki hubungan dengan urusan kenegaraan. Nabi Muhammad lebih sebagai rasul seperti halnya rasul-rasul sebelumnya yang tidak mempunyai misi politik (Nasaruddin Umar, 2002:vi). Ketiga, golongan yang tidak saja menolak pandangan pertama dan kedua, tetapi berpendapat bahwa kendatipun Islam tidak mengenal sistem kenegaraan yang baku, namun secara intrinsik mengandung prinsip-prinsip nilai etika dalam kehidupan bernegara.

Berbagai respons dan apresiasi muncul terkait diskursus relasi agama dan negara dari sejumlah ormas Islam di Indonesia-di luar mainstream organisasi Islam yang dikenal Nahdlatul Ulama (NU) dan Muhammadiyah - seperti: Forum Umat Islam (FUI), Front Pembela Islam (FPI), Majelis Mujahidin Indonesia (MMI), Jamaah Islamiyah (JI) dan Hizbut Tahrir Indonesia (HTI). Khusus ormas Islam yang disebutkan terakhir adalah organisasi yang dikaitkan dengan Hizbut al-Tahrir (HT) dan sangat concern membahas dan menyuarakan pentingnya penegakan syari'at Islam dalam sistem khilâfah.

Hizbut al-Tahrir (HT) didirikan di al-Quds Palestina tahun 1953 oleh Syaikh Taqiyuddin al-Nabhani. Sebelumnya, awal tahun 1953, HT mengajukan izin pendirian partai politik kepada Departemen Dalam Negeri Pemerintah Yordania, namun ditolak, bahkan dilarang karena dianggap ilegal. Sejak awal berdirinya, organisasi ini memiliki cita-cita besar, yakni melangsungkan kehidupan dan mengemban dakwah Islam ke seluruh penjuru dunia. Untuk menegakkan nilai-nilai Islam dalam kehidupan bermasyarakat, harus dilakukan melalui negara dengan menekankan pada Daulah Islâmiyah atau Daulah Khilâfah yang dipimpin oleh seorang khalifah dan dipilih secara demokratis oleh rakyat (Ainur Rofiq al-Amin, 2012: 17).

Hizbut Tahrir Indonesia (HTI) sebagai derivasi HT adalah salah satu gerakan sosial Islam yang mempunyai visi revolusioner. HTI meski memiliki concern yang sama dengan MMIyakni pelaksanaan Syariat Islam - namun strategi dan wacana yang digunakan HTI sedikit berbeda. HTI juga berbeda dengan Jamaah Islamiyah (JI) dan FPI yang cenderung menggunakan kekerasan dalam penegakan dan penerapan syariat Islam. HTI mengandaikan, supremasi sistem pemerintahan Khilâfah Islâmiyah dan formalisasi pelaksanaan syariat Islam di Indonesia hanya bisa tegak bila negeri ini dipimpin oleh sistem kekhalifahan. Perkembangan HTI bisa dibilang menyalip gerakan-gerakan sosial Islam lain seperti FPI dan MMI. HTI kini memiliki kantor di hampir seluruh wilayah di Indonesia. Pada tahun 2001 dan 2007 HTI mampu menghadirkan puluhan ribu massa dari berbagai daerah di Jakarta. Bahkan, pertengahan tahun 2009, HTI berhasil menggelar Musyawarah Ulama Nasional (MUN) yang mengumpulkan sekitar 6000 tokoh Muslim dari seluruh Indonesia di gedung tennis indoor Senayan (Mohammad Iqbal Ahnaf, 2009). 
Burhanuddin Muhtadi (2009: 623-645) mendaku, di tengah kecenderungan sejumlah gerakan sosial Islam yang bermunculan pasca-Orde Baru, HTI memiliki keunikan tipikal yang mengandaikan sistem pemerintahan khilâfah islâmiyah yang bisa menjamin formalisasi dan penerapan syariat Islam di tanah air. Aspek penting lainnya yang membedakan HTI dengan organisasi Islam lainnya adalah pilihan HTI dalam metode atau strategi perjuangan yang tidak menggunakan instrumen demokrasi (pemilu) dalam usaha pencapain cita-citanya. Di titik ini, HTI memilih jalan ekstra parlementer dalam melakukan gerakan sosialnya, di antaranya aksi mobilisasi sosial lewat halaqah dan mengampanyekan integrasi agama dan negara di atas mana hukum Islam diterapkan secara menyeluruh.

\section{HTI: Islam Fundamentalis Tanpa Kekeasan}

Sekitar Januari 2004, sebuah rubrik bulletin $\mathrm{Al}-\mathrm{Wa}$ 'ie, No. 41 tahun IV terbitan HTI, memuat fatwa tentang larangan keterlibatan kaum muslim sebagai pemilih dalam pemilihan calon legislatif dan kepala negara. Menurut rubrik ini, hukum berpartisipasi dalam pemilihan anggota dewan adalah haram. Sejumlah argumen dihadirkan: (1) wewenang mereka dalam membuat dan menetapkan perundang-undangan telah menyalahi ajaran Islam, sebab wewenang tersebut hanyalah milik Tuhan; (2) tugas dan kewajiban mereka semestinya adalah mewakili aspirasi rakyat, menyampaikan koreksi, dan menjadi tempat khalifah meminta masukan tentang urusan-urusan kaum muslim; (3) adanya kemungkinan terpilihnya para wakil yang tidak diketahui kredibilitas dan kemampuannya, bahkan yang beragama selain Islam.

Rubrik ini juga menegaskan keharaman memberikan suara untuk pemilihan kepala negara dalam pemilu, dengan alasan: (1) format pemilihan kepala negara saat ini didasarkan pada sistem demokrasi Barat yang kufur; (2) kepala negara dipilih untuk menjalankan garis-garis besar haluan negara yang didasarkan pada keputusan rakyat, bukan pada Alquran dan Sunnah; (3) adanya kemungkinan terpilihnya wanita, orang kafir, zalim, fasik, bahkan orang bodoh sebagai kepala negara karena mendapatkan dukungan mayoritas.

Ulasan di atas mengandaikan sebuah genre gerakan politik Islam yang anti-demokrasi dan mengusung cita-cita tegaknya hukum dan kehidupan dalam bingkai sistem Islam, yang oleh Bassam Tibi (2001:10-12) dicirikan sebagai "Islam politik". Sementara, pembacaan HTI yang dikotomis-Islam dan non-Islam - terhadap realitas, serta pemikiranya yang literer tentang doktrin agama, diandaikan Ibrahim Abu Bakar (1995:5) sebagai tingkat tertentu dari fundamentalisme keagamaan.

Selain terkait dengan fundamentalisme agama, kemunculan Islam Politik juga dikondisikan oleh beberapa realitas sosial dan politik diantaranya: (1) memburuknya posisi global negara-negara muslim vis a vis Barat; (2) perubahan sosial yang pesat yang terjadi dalam masyarakat muslim berikut pengaruh-pengaruhnya yang mengacaukan; (3) krisis legitimasi dalam sistem-sistem politik yang berorientasi sekuler dan kurangnya partisipasi rakyat dalam proses pembuatan kebijakan, sehingga apa yang disebut Bassam Tibi (2001:56-57) dengan "gelombang ketiga demokratisasi dunia" tidak sampai ke dunia Islam.

Dekade 1970-an dapat dipandang sebagai gelombang awal gerakan fundamentalis Islam di Indonesia yang dipicu oleh dua peristiwa penting: (1) kemenangan partai penguasa (Golkar); (2) peminggiran "Islam politik" (eks-Masyumi).

Namun anehnya, di tengah euforia kemenangan rezim Orde Baru, pada 1972 Amir Hizbut al-Tahrir (HT) Syekh Taqiyuddin al-Nabhani, justeru berkunjung ke Indonesia tanpa halangan, padahal di saat itu rezim melarang kebangkitan eks-Masyumi dan tokoh-tokohnya dalam pentas 
politik nasional. Tidak jelas agenda pemimpin tertinggi HT tersebut di Indonesia, siapa saja tokoh-tokoh Islam yang ia kunjungi. Uniknya pada tahun ini pula, Syaikh Yusuf Qardhawi mampir ke Indonesia. Qaradhawi membawa oleh-oleh buku untuk KH. Abdullah Syafi'i, guru dari Rakhmat Abdullah (founding fathers Jamaah Tarbiyah). Di tahun ini pula masjid kampus pertama dan tersohor di Indonesia masjid Salman ITB Bandung rampung pembangunannya.

Gerakan Islam fundamentalis semakin beranak pinak setelah tahun 1980-an dan era ICMI berkuasa. Ada salafi, Jamaah Tarbiyah, HTI dan Jamaah Tabligh. Mereka menjamur di masjid kampus, gerakan usroh dan rohis. Gerakan dakwah kampus muncul ketika Muh. Natsir dan kawan-kawan mendirikan Dewan Dakwah Islamiyah Indonesia (DDII), yang penguatannya kelak tampak pada aktivitas masjid-masjid kampus semisal Salman-ITB, Salahuddin-UGM, dan Ikhtiar-UNHAS.

Dalam konteks yang paling mutakhir, kalangan pelajar atau mahasiswa yang belajar di Timur Tengah agaknya merupakan saluran paling penting pendistribusian ide-ide Islamis ini. Di tengah situasi sosial politik yang represif rezim Orde Baru kala itu, justeru membuat ide ini kian berkembang dan diminati sebagian kalangan generasi muda muslim perkotaan. Sementara kalangan pesantren justru tidak meminati ide-ide tersebut (Wekke, 2017)

Hal yang menarik dicatat dari studi Greg Fealy dan Anthony Bubalo (1989:84) mengenai pengaruh Islamisme Timur Tengah di Indonesia adalah penegasannya untuk tidak melihat gerakan transnasional ini sebagai gerakan yang monolitik. Jalur transmisi ide-ide islamisme itu menurut studi ini setidaknya mengambil tiga jalur. Pertama, gerakan-gerakan sosial. Di jalur ini transmisi ide dibawa oleh pelajar atau mahasiswa yang belajar di Timur Tengah. Kedua, jalur pendidikan dan dakwah, misalnya Rabithah Alam Islami, International Islamic Relief Organization (IIRO) dan Word Assembly Muslim Youth (WAMY), atau lembaga amal nonpemerintah seperti al-Haramain-yang cabangnya di Indonesia dituding Amerika sebagai organisai pendukung terorisme. Ketiga, jalur publikasi dan internet.

Mengenai jaringan transnasional Hizbut al-Tahrir (HT), dapat digambarkan bahwa HT adalah partai politik internasional, yang aktivitas dan anggotanya telah tersebar ke berbagai negara di seluruh benua. Menurut Rakhmat S. Labib (2011), Ketua DPP HTI, ada beberapa kegiatan HTI yang dikoordinasikan dengan HT di negara-negara lain. Di antaranya adalah konferensi internasional "Khilafah Islamiyah" dan konferensi "Satukan kembali Negeri-negeri Islam". Semua wilayah yang memiliki peluang diperintahkan untuk menyelenggarakan kedua kegiatan itu.

Selain kegiatan ilmiah, bentuk koordinasi gerakan internasional HT dapat kita lihat dalam kasus aksi berikut. Pada 8 Januari 2004, HT wilayah Prancis menyampaikan surat ke kantor Presiden Prancis Jacques Chirac di Elysee Palace. Surat itu berisi pernyataan sikap HT berkenaan dengan pelarangan Jilbab di Prancis. Aksi protes serupa kemudian digelar HTI di depan Kedubes Prancis pada 15 Januari 2004, yang diikuti oleh sekitar 200 orang. Protes yang sama pun digelar di depan Kedubes Prancis di London pada 17 Januari 2004, yang diikuti oleh sekitar 3000 orang (Kurniawan Abdullah, 2005:42).

Bahkan fenomena dua gelombang demonstrasi yang digelar dengan nama "Aksi Islam Damai I" pada 4 November 2016 dan "Aksi Islam Damai II" pada 2 Desember 2016 yang melibatkan jutaan umat Islam tumpah ruah di jalan, tampak jika HTI terlibat sebagai salah satu yang sangat serius mendorong gerakan tersebut. Gelombang demostrasi meledak menyusul dugaan dan untuk selanjutnya status tersangka penistaan agama Islam kepada calon gubernur petahana DKI Basuki Tjahaya Purnama (Ahok). 
Sementara itu, situs resmi HTI yang dibangun sejak 2005, juga menampakkan jaringan transnasional HTI yang sekaligus menyediakan informasi peristiwa dan perkembangan HT di seluruh dunia. Selain memuat berita dalam negeri, situs setempat juga memuat berita dan berbagai pernyataan sikap yang dikeluarkan oleh HT di negara lain. Ada sebelas situs internet yang menjadi akses informasi dunia gerakan HT. Situs-situs ini menggunakan beragam bahasa: Inggris, Arab, Urdu, Rusia, Jerman, Turki, Belanda, Denmark, dan dua situs lainnya berbahasa Indonesia.

Hal yang tak dapat disangkal, dalam melakukan aksi-aksi demonstrasi dan protes HTI tak pernah menggunakan cara-cara kekerasan bahkan mendorong aksi demostrasi damai dan santun. Di titik ini, teori-teori gerakan sosial semisal "teori mobilisasi sumberdaya" (resource mobilization theory), "teori peluang politik" (political opportunities theory), dan "teori bingkai" (framing theory), tak mampu menjelaskan mengapa HTI tetap menentang cara-cara kekerasan dan menjadi distingsi dengan gerakan radikal-fundamentalisme Islam lainnya di Indonesia.

Hal tersebut dapat dipahami, terutama ketika mencoba melacak corak pemikiran politik HTI. Seperti diketahui terdapat tiga genre pemikiran politik dalam kaitan relasi agama dan negara. Pertama, "integralistik" yang mengandaikan keterkaitan secara substantif antara ide-ide Islam universal dan gerakan politik lokal; kedua, "simbiotik" yang meletakkan relasi timbal balik dan saling membutuhkan; dan ketiga, "sekularistik" yang memisahkan secara tegas antara agama dan negara. HTI, dalam bersikap tampaknya memilih corak "integralistik".

Karena itu, meskipun HTI telah menjadikan khilafah sebagai bentuk negara transnasional yang dicita-citakan yang bertujuan: (1) melanjutkan kehidupan Islami dan mengemban dakwah islamiyah ke seluruh penjuru dunia, dan (2) mendorong kebangkitan umat Islam dengan cara yang benar, melalui pola pikir yang cemerlang dan tercerahkan seperti diteladankan para pemimpin dan intelektual Islam di masa kejayaannya yang silam; namun caracara yang dintrodusir tidak melalui kekerasan.

\section{Kesimpulan}

HTI sebagai sebuah institusi pergerakan Islam fundamentalis dan transnasional, memiliki karakteristik yang khas jika dibandingkan dengan kelompok radikal-fundamentalis Islam yang lain. Terutama dalam melihat relasi agama dan negara, berikut sikap politik dalam menyuarakan dan melakukan aksi protes dan demonsnstrasi, HTI memilih paradigma "integralistik", dan karena itu mengandaikan cara-cara damai, santun, dan anti kekerasan. Dengan karakteristiknya itu, dapat dipahami mengapa HTI sebagai gerakan sosial, kendati secara tegas bercita-cita mendirikan negara transnasional khilafah, tetap mendapat simpati publik di tanah air.

\section{Daftar Pustaka}

, “Agama dan Negara dalam Islam: Telaah Atas Fiqh Siyasi Sunni”, dalam Budhy Munawar-Rachman (Ed.), Kontekstualisasi Doktrin Islam dalam Sejarah, Cet. 1; Jakarta: Yayasan Paramadina, 1994.

, "Disartikulasi Pemikiran Politik Islam"? Kata Pengantar dalam Oliver Roy, Gagalnya Islam Politik, Jakarta: Serambi, tth.

, "Kelompok Radikal Muslim" dalam Tempo, Edisi 26 Mei - 1 Juni 2003.

, A Fundamental Quest: Hizb alTahrir and The Search for The Islamic Caliphate, London: Grey Seal, 1996. 
, Ancaman Islam: Mitos atau Realitas (terj.), Cet. III; Bandung: Mizan, 1996.

, Daulah Islam, Jakarta: HTI Press, 2007.

, Dialog Keterbukaan Artikulasi Nilai Islam dalam Wacana Sosial Politik Kontemporer, Editor: Edy A. Effendi, Cet. Ke-1; Jakarta: Paramadina, 1998.

, Gerakan Islam Kontemporer di Indonesia, Jakarta: Diva Pustaka, 2006.

, HTI dan PKS Menuai Kritik: Perilaku Gerakan Islam Politik Indonesia, Cet. 1; Yogyakarta: JK-SG-UMY bekerjasama dengan Pustaka Pelajar, 2013.

, Islam Between Culture and Politics, New York: Palgrave, 2001.

, Islam dan Negara: Transformasi Pemikiran dan Praktek Politik Islam di Indonesia, Jakarta: Paramadina, 1998.

, Islam dan Politik Era Orde Baru , Jakarta: Logos, 2001.

, Islam Doktrin dan Peradaban: Sebuah Telaah Kritis tentang Masalah Keimanan, Kemanusiaan, dan kemodernan, Jakarta: Paramadina, 1992.

, Islam Reformis: Dinamika Intelektual dan Gerakan, Ed. 1; Jakarta: PT. RajaGrafindo Persada, 1999.

, Islam, Pancasila dan Asas Tunggal, Cet. II; Jakarta: PT. Paradigma Press, 1984.

, Manha>j Hizb al-Tahri>r fi> al-Taghyi>r, t.tp: Hizb al-Tahrir, 1989.

, Mengurai Hubungan Agama dan Negara, Jakarta: Grasindo, 1999.

, Negara Islam Tinjauan Faktual Upaya Rasulullah Saw. Membangun Daulah Islamiyyah hingga masa Keruntuhannya, terj. Umar Faruq, Bogor: Pustaka Thariqul Izzah, 2000.

, Nidham al-Hukmi fi al-Islam, Terj. Moh. Maghfur Wahid "Sistem Pemerintahan Islam: Doktrin Sejarah dan Realitas Empirik”, Cet. Ke-1; Bangil: Al Izzah, 1996.

'Abud,'Abd al-Ghani, Al-Daulah al-Islamiyyah wa al-Daulah al-Ma'a>shirah, Mesir: Da>r alFikr al-'Arabi>, 1981.

Abdullah, Kurniawan, "Fenomena Gerakan Politik Islam Ekstraparlementer: Hizbut Tahrir Indonesia", dalam jurnal Dialog, Edisi 1 Tahun ke-3, 2005.

Abu Bakar, Ibrahim, "Fundamentalisme Islam: Istilah yang dapat Menyesatkan”, dalam Ulumul Qur'an, no. 3, vol. IV, tahun 1993.

Ahmad Syafi'i Maarif, Islam dan Masalah Kenegaraan Studi tentang Percaturan dalam Konstituante, Cet. Ke-1; Jakarta: LP3ES, 1996.

Ahmad, Kamaruzzaman Bustaman, Islam Historis: Dinamika Studi Islam di Indonesia, Cet. Ke1; Yogyakarta: Galang Press, 2002.

Ahnaf, Mohammad Iqbal, Between revolution and reform: The future of Hizbut Tahrir Indonesia, Journal Dynamics of Asymmetric Conflict, London: Routledge, 2009.

al-Amin, Ainur Rofiq, Membongkar Proyek Khilafah ala Hizbut Tahrir di Indonesia, Cet. I; Yogyakarta: LKiS, 2012.

Al-Bahnasawi, Salim Ali, Wawasan Sistem Politik Islam, Jakarta: Al-Kautsar, 1996.

Al-Banna, Jamal, Al-Isla>m: Di>n wa Ummah Lai\}sa Di>nan wa Daulatan, diterjemahkan Jamadi Sunardi dengan "Runtuhnya Negara Madinah: Islam Kemasyarakatan versus Islam Kenegaraan", Cet. I; Yogyakarta: Pilar Media, 2005.

al-Kailany, Musa Zaid, Al-Haraka>t al-Islamiyah fi> al-Urdu>n: Dira>sat wa Taqyi>m Ikhwa $>n$ al-Muslimi>n, Hizb al-Tahri>r al-Islamy, Amman: Dar al-Basyar li am-Nasyr wa al-Tawzi', 1990.

al-Mubarak, Muhammad, Sistem Pemerintahan dalam Perspektif Islam, alih bahasa: Firman Hariyanto, Cet. Ke-1, Solo: Pustaka Mantiq, 1995.

Al-Wa'ie, No. 41 tahun IV, Januari 2004. 
Amal, Taufik Adnan dan Samsu Rizal Panggabean, Politik Syariat Islam: dari Indonesia hingga Nigeria, Jakarta: Pustaka Alvabet, 2004.

An-Nabhani, Taqiyuddin, Mafahim Hizbut Tahrir, Jakarta: Hizbut Tahrir Indonesia, 2007.

Azhari, Muh. Tahir, Negara Hukum: Suatu Studi tentang Prinsip-prinsipnya Dilihat dari Segi Hukum Islam, Implementasinya pada Periode Negara Madinah dan Masa Kini, Cet. I; Jakarta: PT. Bulan Bintang, 1992.

Aziz, Abdul, Chiefdom Madinah: Salah Paham Negara Islam, Cet. I; Jakarta: Pustaka Alvabet, 2011.

Azra, Azyumardi, Pergolakan Politik Islam: Dari Fundamentalisme, Modernisme, hingga PostModernisme, Jakarta: Paramadina, 1996.

Billings, Dwight B., "Religion as Opposition: A Gramscian Analysis", dalam American Journal of Sociology, vol. 96, no. 1, Juli 1990.

Bruinessen, Martin van, Rakyat Kecil, Islam dan Politik, diterjemahkan oleh Farid Wajidi, Yogyakarta: Yayasan Bentang Budaya, 1999.

Choudhury, G.W., Islam and The Modern MuslimWorld, Second Edition; Kuala Lumpur: WHS Publication, Sdn Bhd, 1994.

Departemen Agama RI, Al-Qur'an dan Terjemahnya, Semarang: Toha Putra, 1989.

Djaelani, Abdul Qadir, Sekitar Pemikiran Politik Islam, Cet. I; Jakarta: Media Dakwah, 1994.

Effendy, Bahtiar, Agama dan Dialog Antar Peradaban, Cet. I; Jakarta: Paramadina, 1996.

Eickelman, Dale F. and James Piscatori (Eds.), Muslim Politics, New Jersey: Pricenton University Press, 1996.

Eldridge, Philip J, Non-Government Organizations and Democratic Participation in Indonesia, Kuala Lumpur: Oxford University Press, 1995.

Esposito, John L., Islam dan Politik, Jakarta: Bulan Bintang, 1990.

Farouki, Suha Taji-, "Islamists and Threat of Jihad: Hizb al-Tahrir and al-Muhajiroun on Israel and Jews", dalam Middle Eastern Studies, 36: 4 Oktober 2000.

Fealy, Greg dan Anthony Bubalo, Joining the Caravan?: The Middle East, Islamism and Indonesia terjemahan Akh. Muzakki dengan "Jejak Kafilah: Pengaruh Radikalisme Timur Tengah di Indonesia", Cet. I; Bandung: Mizan, 2007.

Ghalyun, Burhan, Naqd al-Siya>sah: al-Daulah wa al-Di>n, Cet. III; Beirut: al-Muassasah al'Arabiyyah al-Dira>>sat al-Nasyr, 1994.

Giddens, Anthony. Sociology, Oxford: Polity Press, 1993.

Harper, Charles L., Exploring Social Change, New Jersey: Prentice-Hall, 1989.

Hizbut Tahrir Indonesia, Manifesto Hizbut Tahrir untuk Indonesia: Indonesia, Khilafah dan Penyatuan Kembali Dunia Islam, Jakarta: Hizbut Tahrir Indonesia, 2009.

Hizbut Tahrir Indonesia, Menegakkan Syariat Islam, Jakarta: HTI, 2002.

Hizbut Tahrir, Mengenal Hizbut Tahrir: Partai Politik Islam Ideologis, Bogor: Pustaka Thariqul Izzah, 1994.

Jalaluddin, Ahmad, Al-Siya>sah al-Iqtisha>diyah fi Daw al-Mas\}lahah al-Syar'iyyah, Malang: UIN Malang Press, 2008.

Jamhari dan Jajang Jahroni, Gerakan Salafi Radikal di Indonesia, Cet. I; Jakarta: PT. RajaGrafindo Persada, 2004.

Jindan, Khalid Ibrahim, Teori Politik Islam Telaah Kritis Ibn Taimiyah Tentang Pemerintahan Islam, terj. Masrohin, Surabaya: Risalah Gusti, 1995.

Jurdi, Syarifuddin, Pemikiran Politik Islam Indonesia: Pertautan Negara, Khilafah, Masyarakat Madani dan Demokrasi (Cet. I; Yogyakarta: Pustaka Pelajar, 2008. 
Kamaruzzaman, Relasi Islam dan Negara: Perspektif Modernis dan Fundamentalis, Cet. I; Magelang: IndonesiaTera, 2001.

Khalf Allah, Muhammad Ahmad, Al-Qur'a>n wa al-Daulah, Mesir: Maktabah al-Injilu alMishriyyah, 1973.

Khalimi, Ormas-ormas Islam: Sejarah, Akar Teologi dan Politik, Cet. ke-1; Jakarta: Gaung Persada Press, 2007.

Khan, Qamaruddin, Political Concepts in the Qur'an, Lahore: Islamic Book Foundation, 1982.

Kuntowijoyo, Identitas Politik Umat Islam, Cet. II; Bandung: Mizan, 1997.

Latif, Yudi, Intelegensia Muslim dan Kuasa: Genealogi Intelegensia Muslim Indonesia Abad ke20, Bandung: Mizan, 2005.

Madjid, Nurcholish dkk., Problematika Politik Islam di Indonesia, Jakarta: Grasindo, 2002.

Mardimin, J. (Ed.), Mempercakapkan Relasi Agama dan Negara: Menata Ulang Hubungan Agama dan Negara di Indonesia, Cet. I; Yogyakarta: Pustaka Pelajar, 2011.

Mathar, Moch. Qasim, Perkembangan Pemikiran Politik di Indonesia pada Masa Orde Baru dalam Perspektif Islam, Cet. 1; Makassar: Alauddin Press, 2011.

Menoh, Gusti A.B., "Mengurai Hubungan antara Agama dan Negara dalam Pemikiran Jurgen Habermas", dalam jurnal Titik Temu, Vol. 4, No. I, Juli-Desember 2011.

Moussali, Ahmad S., Islamic Fundamentalism: Myth and Realities, Ithaca: Ithaca Press, 1998.

Mubarak, M. Zaki, Genealogi Islam Radikal di Indonesia: Gerakan, Pemikiran dan Prospek Demokrasi, Cet. I; Jakarta: Pustaka LP3ES, 2008.

Mufid, Ahmad Syafi'i (Ed.), Perkembangan Paham Keagamaan Transnasional di Indonesia, Ed.1; Cet. 1; Jakarta: Puslitbang Kehidupan Keagamaan Badan Litbang dan Diklat Kementerian Agama RI, 2011.

Muhtadi, Burhanuddin, The Quest for Hizbut Tahrir in Indonesia, Koninklijke Brill NV, Leiden: Asian Journal of Social Science 37, 2009.

Mulia, Musda, Negara Islam: Pemikiran Politik Husain Haikal, Jakarta: Paramadina, 2001.

Mulkhan, Abdul Munir dan Bilveer Singh, Demokrasi di Bawah Bayangan Mimpi N-11: Dilema Politik Islam dalam Peradaban Modern, Cet. 1; Jakarta: PT. Kompas media Nusantara, 2011.

Nash, June (Ed), Social Movement, an Anthropological Reader, Oxford: Blackwell Publishing Ltd., 2005.

Nashir, Haedar, Islam Syariat: Reproduksi Salafiyah Ideologis di Indonesia, Cet. 1; Bandung: Mizan, 2013.

Nata, Abuddin, Peta Keragaman Pemikiran Islam di Indonesia, Cet. 2; Jakarta: PT. RajaGrafindo Persada, 2001.

Natsir, M., Agama dan Negara dalam Perspektif Islam, Cet. I; Jakarta: Media Dakwah, 2001.

Noer, Deliar, Gerakan Modern Islam di Indonesi 1900-1942, Cet. Ke-8; Jakarta: LP3ES, 1996.

Nugroho, Taufiq, Pasang Surut Hubungan Islam dan Negara Pancasila, Yogyakarta: Padma, 2003.

Pichardo, Nelson A. "New Social Movement: A Critical Review", dalam Annual Review Sociology, Vol. 23, pp. 441-30, 1997.

Pulungan, J. Suyuthi, Fiqh Siyasah Ajaran, Sejarah dan Pemikiran, Jakarta: PT. RajaGrafindo Persada, 1995.

Qodir, Zuly, Islam Syari'ah vis a vis Negara: Ideologi Gerakan Politik di Indonesia, Cet. I; Yogyakarta: Pustaka Pelajar, 2007. 
Rahmat, M. Imdadun, Ideologi Politik PKS: Dari Masjid Kampus ke Gedung Parlemen, Cet. III; Yogyakarta: LKiS, 2009.

Rathomy, Arief Ihsan, PKS dan HTI: Genealogi dan Pemikiran Demokrasi, Cet. I; Yogyakarta: Laboratorium Jurusan Ilmu Pemerintahan Fisipol UGM, 2005.

Ridha, Abu, Islam dan Politik: Mungkinkah Bersatu?, Cet. I; Bandung: PT. Syaamil Cipta Media, 2004.

Rodhi, Muhammad Muhsin, Hizbut Tahrir, Tsaqafatuhu wa Manhajuhu fi Iqamah Daulah alKhilafah al-Islamiyyah, diterjemahkan oleh Muhammad Bajuri dan Romli Abu Wafa dengan judul "Tsaqofah dan Metode Hizbut Tahrir Dalam Mendirikan Negara Khilafah", Cet. I; Bogor: Al-Azhar Press, 2012.

Rosyada, Dede, et al., Pendidikan Kewargaan (Civic Education): Demokrasi, Hak Asasi Manusia dan Masyarakat Madani, Cet. Ke-1; Jakarta: ICCE UIN Syarif Hidayatullah, 2000.

Rosyadi, Rahmat dan Rais Ahmad, Formalisasi Syari'at Islam dalam Perspektif Tata Hukum Indonesia, Bogor: Ghalia Indonesi, 2006.

Roy, Oliver, The Failure of Political Islam, (London: I.B. Tauris \& Co. Ltd., 1994.

Sabili, edisi 18 Juni 2009.

Sewang, Ahmad M., Hubungan Agama dan Negara: Studi Pemikiran Politik Buya Hamka, Cet. I; Makassar: PPs UIN Alauddin Makassar, 2003.

Sherman, Arnold K. \& Aliza Kolker, The Social Bases of Politics, (California: Wadsworth Publishing Company, 1987.

Singh, Bilveer, The Talibanization of Southeast Asia: Lasing The War on Terror to Islamist Extremists, (London: Praeger Security International, 2007.

Sirry, Mun'im A., Membendung Militansi Agama: Iman dan Politik dalam Masyarakat Modern, Jakarta: Erlangga, 2003.

Sjadzali, Munawir, Islam dan Tata Negara: Ajaran, Sejarah, dan Pemikiran, Jakarta: UI Press, 1991.

Suharko, "Mengurai dan Membangun Basis Legitimasi NGO/Ornop" dalam Jurnal Mandatory, Yohyakarta: IRE,

Syamsuddin, M. Din, "Usaha Pencarian konsep Negara dalam Sejarah Pemikiran Politik Islam", ed. Abu Zahra dalam Politik Demi Tuhan, Bandung: Pustaka Hidayah, 1999.

Taba, Abdul Azîz, Islam dan Negara dalam Politik Orde Baru, Jakarta: Gema Insani Press, 1996.

Tarrow, Sydney, Power in Movement: Social Movement and Contentius Politics, Cambridge: Cambridge Univeisty Press, 1998.

Tibi, Bassam, Ancaman Fundamentalisme: Rajutan Islam Politik dan Kekacauan Dunia Baru, terj. Imron Rosyidi, Zainul Abbas dan Shinta Carolina, Yogyakarta: Tiara Wacana, 2000.

Tim Penulis HTI, Menegakkan Syari'at Islam, Jakarta: HTI, 2000.

Umar, Nasaruddin, (Ed.), dalam Abd. Muin Salim, Fiqh Siyasah: Konsepsi Kekuasaan Politik dalam Al-Qur'an, Cet. III; Jakarta: PT. RajaGrafindo Persada, 2002.

Wahid, KH. Abdurrahman (Ed.), Ilusi Negara Islam: Ekspansi Gerakan Islam Transnasional di Indonesia, Cet. I; Jakarta: The Wahid Insitute, 2009.

Wahid, Marzuki (Ed.), Jejak-jejak Islam Politik: Sinopsis Sejumlah Studi Islam Indonesia, Cet. I; Jakarta: Direktur Perguruan Tinggi Agama Islam Ditjen Kelembagaan Agama Islam, 2004. 
Wahyudi, Andi, Muhammadiyah dan Gonjang-Ganjing Politik: Telaah Kepemimpinan Muhammadiyah Era 1990, Darmawan (Ed.), Cet. Ke-1,; Yogyakarta: Media Pressindo, 1999.

Wasburn, Philo C., Political Sociology Approaches, Concepts and Hypotheses, New Jersey: Prentice-Hall, 1982.

Wekke, Ismail Suardi. "Integrasi Pendidikan Islam dan Pembelajaran Kewirausahaan di Pesantren Minoritas Muslim." Fenomena 9, No. 1, 2017: 1-24.

Wekke, Ismail Suardi. "Politik, Agama dan Negara: Pemerintahan Islam di Malaysia". Millah: Jurnal Studi Agama, 12, No. 2, 2016: 291-328.

Wijaya, Aksin, "Nalar Agama dan Nalar Negara: Telaah Historis Relasi Agama dan Negara dalam Tradisi Islam", Pengantar dalam Hidup Beragama dalam Sorotan UUD 1945 dan Piagam Madinah, Cet. I; Ponorogo: STAIN Ponorogo Press, 2009.

Zada, Khamami, Islam Radikal: Pergulatan Ormas-ormas Islam Garis Keras di Indonesia, Cet. I; Jakarta: Teraju, 2002. 